\title{
КОНЦЕПТУАЛЬНЫЕ ПОДХОДЫ К КЛАССИФИКАЦИЯ НАЦИОНАЛЬНЫХ УЧЕТНО-СТАТИСТИЧЕСКИХ СИСТЕМ
}

\author{
(C) 2018 Петров Александр Михайлович \\ доктор экономических наук, профессор Департамента учета, анализа и аудита \\ Финансовый университет при Правительстве Российской Федерации \\ 125993, г. Москва, Ленинградский пр-т, д. 49 \\ E-mail: palmi@inbox.ru \\ (c) 2018 Антонова Ольга Витальевна \\ кандидат экономических наук, доцент Департамента учета, анализа и аудита \\ Финансовый университет при Правительстве Российской Федерации \\ 125993, г. Москва, Ленинградский пр-т, д. 49 \\ E-mail: olgavit@mail.ru
}

В мире есть большое количество систем учета. Различия данных моделей вызваны историческими причинами, особенностями окружающей среды, где функционируют предприятия. Среди огромного количества классификаций по разным принципам можно выделить основные две классификации. В первой деление происходит по «географическому» принципу: британо-американская система, континентальная система, латиноамериканская система. Согласно второй - типизация проводится не только методом выделения характерных черт и типов, но и иерархическим подчинением друг другу. Верхний уровень определяет то, на какие цели учетная система ориентируется. Потом проводится градация зависимо от того, на что страна ориентируется в построении системы учета - на теоретические разработки, или практические потребности законодательства или делового мира.

Ключевые слова: бухгалтерский учет, отчетность, статистика, национальная модель учета.

Международная практика бухгалтерского учета многогранна и неоднородна. В первую очередь, различают международные стандарты и национальные стандарты.

Национальные стандарты учета каждой страной разрабатываются самостоятельно. Ведущими странами в сфере национальных стандартов учета являются Великобритания и США, что определяется ролью данных стран на финансовых международных рынках. В различных странах национальные стандарты учета называются по-разному; помимо этого, разработкой их занимаются разные органы: в некоторых странах это - государственные органы, в иных профессиональные организации.

Международные стандарты учета внедряются и разрабатываются на 2-х уровнях: международном мировом и региональном. В региональном аспекте главная роль принадлежит Комиссии по бухгалтерскому учету ЕС, регулирующей данные вопросы в странах ЕС. Разработкой мировых стандартов занимается несколько организаций: Международная Федерация бухгалтеров, Комитет по международным стандартам учета, Межправительственная группа экспертов по международным стандартам отчетности и учета Центра транснациональных корпораций ООН, Организация экономического развития и сотрудничества.

Работа по классификации систем учета ведется с нач. 20 в. В 1911 г. Генрих Ренд Хэтфилд в докладе, который был представлен им на Американской ассоциации присяжных бухгалтеров, указал на влияние Франции на учет группы стран. В основу классификации разными учеными закладывались разные классификационные признаки.

Классификации на основе «сферы влияния». По данной теории в традиционных ассоциациях одна «материнская страна» влияет на бухгалтерскую практику иных государств. На основании данной теории Л. Сайдлер приводит три группы:

- британская модель, которая влияет на индийскую и австралийскую системы учета;

- американская модель, которая влияет на Мексику и на большинство стран Южной Америки, а также на Японию и Израиль;

- французская модель, которая свое воз- 
действие распространила страны Средиземного моря и южную Европу, на такие страны Южной Америки, где торговые кодексы основаны на Кодексе Наполеона.

Анализируя подход Л. Сайдлера, Г. Превитс не согласен с тем, что США оказывают влияние на страны Южной Америки, а к тем государствам, которые испытали влияние Великобритании, он добавляет Новую Зеландию, Канаду, Нигерию, Южную Африку, Британскую Вест-Индию, Грецию, Таиланд и некоторые страны Южной Америки.

Классификация, которая основана на субъективном подходе. Первую классификацию провел Г. Мюллер. Он утверждал, что можно выделить 4 модели систем учета на основе общих типов их развития:

- основанная на микроэкономике, которая считается отраслью экономики (Нидерланды);

- основанная на макроэкономике, которая рассматривается как инструмент экономической национальной политики (Швеция);

- унифицированного учета, которая применяется правительством для контроля и мониторинга за экономикой и основана на стандартизованных определениях, представлении и измерениях данных (Франция);

- являющаяся независимой дисциплиной, которая развивается исходя из задач бизнеса, когда воздействие текущей практики бухгалтерии - наиболее важный фактор становления принципов бухгалтерии (Великобритания и США).

Также Г. Мюллер предлагает альтернативную классификацию, которая основана на десяти разновидностях экономической ситуации в стране.

Примеры государств с данными типами:

- страны Британского Содружества;

- Нидерланды, Канада, США;

- страны континентальной Европы, кроме государств Скандинавии, Нидерландов и Германии;

- Япония и Германия;

- Мексика и Израиль;

- страны Скандинавии;

- развивающиеся страны Дальнего и Ближнего Востока;

- страны Южной Америки;

- Польша, Россия, Беларусь, Украина;

- страны Африки, кроме Южной Африки.

Американская бухгалтерская ассоциация предложила «субъективную» систему классификации по 5 зонам:

- франко-испано-португальской;

- британской;

- голландской/немецкой;

- стран Восточной Европы;

- американской.

Классификация, которая основана на систематизации групповых различий (т.е. статистическая).

Многие ученые классифицируют системы учета, сводя их в группы на основании кластерного анализа элементов, которые выявляются при практическом использовании этих систем при проводимых исследованиях; особенно ценными считаются отчеты агентства Price Waterhouse, послужившие основой для классификации Р. Нера, У. Франка и Де Коста.

Де Коста выделяет 2 кластерные группы, одна из которых основана на системах учета, которые используются в Великобритании и бывших ее колониях, а вторая - на остальных. Системы Нидерландов и Канады не попадают ни в одну из групп.

Р. Нер провел анализ различий между способами предоставления и оценки информации и выделил 7 групп на основе методов оценки и 10 на основе представления информации.

У. Франк, анализируя ту же информацию, выделил 4 модели: Континентальной Европы; Британского Содружества; США; Латинской Америки.

Классификация национальных систем учета разрабатывалась и российскими специалистами. В основу ее положена однородность тех экономических факторов, которые определяют национальную систему учета. Российские специалисты предпочтение отдают 3-м моделям учетных систем: латиноамериканской; европейской (континентальной); англо-американской.

В табл. 1 нами систематизированы признаки, которые объединяют национальные системы в группы по последней классификации.

Приведенная классификация - более приемлема для применения при изучении проблем стандартизации учета на региональном уровне. Подтверждение этому - принятия большей частью стран континентальной модели Директивы ЕС и применения англо-американской модели учетных стандартов GAAP. Страны латиноамериканской модели объединяет также тенденция стандартизации учета на региональном уровне. 
Таблица 1. Классификация систем учета

\begin{tabular}{|c|c|c|}
\hline Англо-американская модель & Континентальная модель & Латиноамериканская модель \\
\hline $\begin{array}{l}\text { Объединяет учетные нацио- } \\
\text { нальные системы таких стран, } \\
\text { как Великобритания, Австралия, } \\
\text { Израиль, Гонконг, Канада, Индия, } \\
\text { Нидерланды, Кипр, Сингапур, } \\
\text { Пакистан, ЮАР, США и некоторых } \\
\text { иных англо-говорящих стран }\end{array}$ & $\begin{array}{l}\text { Объединяет учетные националь- } \\
\text { ные системы Бельгии, Австрии, } \\
\text { Греции, Германии, Испании, Да- } \\
\text { нии, Норвегии, Италии, Франции, } \\
\text { Португа-лии, Швеции, Швейцарии } \\
\text { и некоторых других стран Европы. } \\
\text { К данной модели близка нацио- } \\
\text { нальная система ведения учета в } \\
\text { Японии и России }\end{array}$ & $\begin{array}{l}\text { Объединяет учетные националь- } \\
\text { ные системы стран Южной Аме- } \\
\text { рики по общности языка, общему } \\
\text { прошлому }\end{array}$ \\
\hline $\begin{array}{l}\text { Во всех странах, которые относят- } \\
\text { ся к этой модели, велико влия- } \\
\text { ние Великобритании и США. В } \\
\text { ведущих странах развиты рынки } \\
\text { ценных бумаг, отмечается высокий } \\
\text { профессионализм бухгалтеров и } \\
\text { пользователей учетной информа- } \\
\text { ции. Ориентация отчетности на- } \\
\text { правлена на нужды кредиторов и } \\
\text { инвесторов предприятия. Особен- } \\
\text { но важно исчисление реального } \\
\text { финансового результата деятель- } \\
\text { ности предприятия }\end{array}$ & $\begin{array}{l}\text { Практика учета одной страны от- } \\
\text { личается от практики учета иной. } \\
\text { Бизнес с банками имеет тесные } \\
\text { связи. Ориентация финансовой } \\
\text { отчетности на потребности ин- } \\
\text { весторов не является приоритет- } \\
\text { ной задачей. Бухгалтерский учет } \\
\text { регламентируется законодательно, } \\
\text { отличается значительной консер- } \\
\text { вативностью и высокой степенью } \\
\text { вмешательства государства в учет- } \\
\text { ную практику (т.е. обязательное } \\
\text { использование плана счетов) }\end{array}$ & $\begin{array}{l}\text { Отличительная особенность } \\
\text { бухгалтерской отчетности данных } \\
\text { стран - корректировка на инфля- } \\
\text { цию. Учет в целом ориентирован } \\
\text { на потребности плановых государ- } \\
\text { ственных органов и контроль за } \\
\text { выполнением налоговой поли-ти- } \\
\text { ки. Приемы и способы бухгал- } \\
\text { терского учета, используемые на } \\
\text { предприятия, имеют высокий } \\
\text { уровень унификации }\end{array}$ \\
\hline $\begin{array}{l}\text { Задача информационного обеспе- } \\
\text { чения потребностей государства в } \\
\text { лице налоговых органов выведена } \\
\text { за рамки системы финансового } \\
\text { учета и подготовки финансовой } \\
\text { отчетности }\end{array}$ & $\begin{array}{l}\text { Бухгалтерская отчетность ори- } \\
\text { ентирована на удовлетворение } \\
\text { информационных потребностей } \\
\text { налоговых и других органов госу- } \\
\text { дарственной власти }\end{array}$ & \\
\hline
\end{tabular}

Можно отметить и затруднения, которые возникают при классификации систем учета. Так, при идентификации групп в разных системах учета необходимо решать, что предпочесть: реалии практики или нормативы. К примеру, в Швеции есть набор нормативных принципов, однако на практике обычно исходят из принципа представления информации только в интересах инвесторов.

Определение классификационных групп встречает препятствие, когда в стране система учета нестабильна. Так, в 60-е гг. 20 в. Новая Зеландия начала отделяться от Великобритании, хотя многие положения системы учета данной страны были взяты напрямую из тех стандартов, которые разработаны Английским институтом бухгалтеров.

При проблемах и различных подходах к классификации национальных систем учета саму ее возможность переоценить трудно. Близость национальных систем тех стран, которые принадлежат к одной группе, говорит о возможности гармонизации учета на международном уровне.

Из изложенного можно сказать, что:

- возможность объединения национальных стандартов в группы обусловливает возмож- ности сглаживания между ними различий при стандартизации;

- процесс сближения экономик стран при глобализации мирового хозяйства способствует стандартизации учета на мировом уровне.

Различия национальных систем учета вызваны объективными обстоятельствами:

1. Влияние теоретических концепций учета, которые доминируют в стране. Системы стандартов основаны на научных определенных концепциях. В разных странах могут доминировать различные концепции, что определяет и разницу в подходах к формированию стандартов. К примеру, в основании концепции бухгалтерского учета США лежит позитивная теория, которая отрицает оценочные суждения и большое внимание уделяет финансовым потокам компании.

В Нидерландах большую популярность имеет другой подход: «экономика для бизнеса». В основании этого подхода - работы Теодора Лимперга, где он обосновал оценки через восстановительную стоимость; данная теория развивалась не в ответ на инфляционные проблемы, а на основании экономической науки.

Национальная система учета в РФ в пери- 
од социализма находилась под прессом теорий политэкономии. Сегодня на формирование российской системы учета большое влияние оказывает Концепция учета в рыночной экономике РФ, которая ориентирует на получение достоверной информации о деятельности организаций, которая полезна для пользователей.

2. Расстановка политических сил. Стандартизация учета в обществе тяготеет к политическим явлениям. Принятие системы учета имеет экономические последствия, которые могут быть невыгодны или выгодны влиятельным группам общества. Доминирование разных политических сил влияет на решения в сфере стандартизации учета.

К примеру, высокая степень унификации учета характерна для тех стран, где государство оказывает влияние на экономику. При административно-командной системе в РФ была другая система учета, чем та, которая требовалась при переходе к рыночной экономике.

3. Экономическая ситуация в стране. Регламентация учета осуществляться может и для регулирования экономических проблем. Правительство может поддержать стандарты учета, поощряющие или, наоборот, препятствующие использованию компаниями каких-либо методов учета обязательств, начисления амортизации, учета затрат на производство и т.д. Особенно это сказывается в странах, где налоговая система мало стимулирует экономическую эффективность налоговых платежей, а налогоплательщики не информируются или дезинформируются об использовании сумм налогов.

Еще один аспект - это уровень инфляции в стране. Высокая инфляции приводит к созданию бухгалтерской инфляционной системы, когда нужны частые переоценки показателей отчетности. Примеры инфляционных бухгалтерий есть в странах Латинской Америки

4. Пользователи финансовой информации и те цели, которые они перед собой ставят. Информация, которая содержится в отчетности предприятий, соответствует потребностям определенных групп пользователей. От того, интересы каких пользователей в стране доминируют, зависит набор показателей, которые раскрываются в финансовой отчетности.

К примеру, в Великобритании и США преобладают интересы инвесторов, во многих европейских странах - кредиторов. В некоторых странах доминируют интересы государственных, в особенности налоговых, органов. Доминирование каких-либо пользователей финансовой информации при определении набора показателей отчетности зависит во многом от основных источников финансирования организаций.

Ориентированность компаний Великобритании и США на капитал инвесторов обусловливает приоритет этой группы пользователей перед другими. Напротив, финансы европейских компаний зависят в большей степени от кредитов банков.

5. Исторические национальные традиции. Национальные системы учета по-разному формировались на протяжении длительного времени в каждой стране. Общая тенденция их развития - непрерывное совершенствование и изменение, но обществу свойственно стремление сохранить прежние традиции. К примеру, национальные стандарты стран Европы, которые имеют давние традиции, между собой отличаются. В то же время многие из тех стран, которые тесно связаны с США, часто применяют американские национальные стандарты учета GAAP.

Следовательно, наличие объективных причин, которые вызывают различия в национальных системах учета, препятствует их стандартизации на международном уровне. И все-таки реальность в том, что различия в национальных стандартах можно обойти, если выделить группы стран с похожими экономическими и культурными традициями и подходами к системе учета. Это будет залогом успеха в объединении национальных систем учета, прежде всего, через их классификацию по определяющим основаниЯм [12].

\section{Библиографический список}

1. Петров А.М. Международные стандарты финансовой отчетности: учебник. Москва, 2019.

2. Петров А. М. Современные концепции бухгалтерского учета и отчетности: учебник. Москва. 2018.

3. Бабаев Ю.А., Петров А. М. Расчеты организации: учет, контроль и налогообложение. учебно-практическое пособие для студентов высших учебных заведений, обучающихся по специальности 080109 “Бухгалтерский учет, анализ и аудит”: учебник. Москва. 2010. 
4. Петров А.М., Мельникова Л.А. Затраты и расходы в системе бухгалтерского учета и налогообложения // Проблемы современной экономики. 2013. № 4 (48). С. 179-183.

5. Петров А.М. Организационный механизм контроля за движением дебиторской и кредиторской задолженности // Экономический анализ: теория и практика. 2006. № 18 (75). С. 54-62.

6. Бабаев Ю.А., Петров А.М. Бухгалтерский учет и контроль дебиторской и кредиторской задолженности: учеб. практ. пособие. Москва. 2004.

7. Бабаев Ю.А. Теория бухгалтерского учета: учебник / Ю.А. Бабаев, А.М. Петров. Под ред. Ю.А. Бабаева. Москва. 2011. (Изд. 5-е, перераб. и доп.)

8. Петров А.М. Контроль за движением дебиторской и кредиторской задолженности // Современный бухучет. 2004. № 9. C. 38.

9. Бабаев Ю.А., Друцккая М.В., Кеворкова Ж.А., Листопад Е.Е., Петров А.М. Бухгалтерский учет, анализ и аудит внешнеэкономической деятельности: учебник для студентов обучающихся по специальности 080109 “Бухгалтерский учет, анализ и аудит”. Под редакцией Ю.А. Бабаева. Москва. 2010.

10. Мельникова Л.А., Петров А.М. Бухгалтерский учет финансовых резервов и оценочных обязательств: монография. Москва: 2015.

11. Бабаев Ю.А., Петров А.М. Бухгалтерский учет в торговле и общественном питании: учебное пособие. Москва. 2015.

12. Анциферова И.В. Бухгалтерский финансовый учет: практикум. Москва. 2016. 368 с.

Поступила в редакцию 15.12.2018 